\title{
Genotype x Environment Analysis of Blackgram (Vigna mungo L. Hepper) Cultures over Open Condition by Eberhart and Russell Model
}

\author{
V.B. Gambhire, D.M. Raut*, S.J. Dhakulkar and Jiji joseph \\ Department of Plant Breeding and Genetics, COH, Vellanikkara, Thrissur- 680656, Kerala, India \\ *Corresponding author
}

\begin{tabular}{|c|c|}
\hline & A B S T R A C T \\
\hline Keywords & \multirow{6}{*}{$\begin{array}{l}\text { Ten cultures including four local checks T9, TAU1, Sumanjana and Syama } \\
\text { of blackgram were evaluated over open conditions to study the stability } \\
\text { parameters viz., regression coefficient (bi) and mean square deviation ( } \mathrm{S}^{2} \text { di) } \\
\text { from linear regression along with per se performance for days to flowering, } \\
\text { plant height, number of branches per plant, number of pod bearing branches } \\
\text { per plant, number of pods per plant, pod length, number of seeds per pod, } \\
\text { test weight, yield per plant and protein content. Variance due to genotype, } \\
\text { environment, genotype } \mathrm{x} \text { environment, environment (linear) was significant } \\
\text { in all traits except plant height and test weight. Based on the stability } \\
\text { analysis and ranking the genotypes T6, was the best followed by T9 and T5 } \\
\text { suitable for cultivation under open condition. }\end{array}$} \\
\hline $\begin{array}{l}\text { Blackgram, } \\
\text { Regression }\end{array}$ & \\
\hline coefficient, & \\
\hline $\begin{array}{l}\text { Genotype, Stability, } \\
\text { environment. }\end{array}$ & \\
\hline Article Info & \\
\hline $\begin{array}{l}\text { Accepted: } \\
\text { 21 July } 2017 \\
\text { Available Online: } \\
\text { 10 September } 2017\end{array}$ & \\
\hline
\end{tabular}

\section{Introduction}

Blackgram (Vigna mungo (L.) Hepper) is an important short duration pulse crop occupying unique position in Indian agriculture. Its seeds are highly nutritious and used in the preparation of many popular dishes. Pulses are part of the daily diet of vegetarians world over.

They are rich in protein (20-30\%) and are an excellent source of dietary fiber, low molecular weight carbohydrates, essential aminoacids, poly unsaturated fatty acids and range of micronutrients. In recent years there has been an increase in consumption of pulses in several developed countries where they are increasingly considered as health food.
In Kerala, cultivation of pulses especially black gram as third crop i.e., in summer fallows in paddy growing areas was a common practice by the farmers.

However, this trend has come down in the near past due to non-availability of labourers for harvesting and low yield of traditional varieties. Raising blackgram in coconut gardens seems as a viable option to increase area of cultivation. In Kerala, high yielding varieties suited to both open and shaded conditions are not available. In the present investigation, an attempt has been made to study the stability of 14 genotypes over open condition. 


\section{Materials and Methods}

The present study was undertaken during kharif, rabi and summer season in open (light) condition. Experiment was carried out at Department of Plant Breeding and Genetics; College of Horticulture.

During the period August 2013-December 2014.Ten genotypes of blackgram including four checks TAU-1, T9, Sumanjana and Syama.

Design used for experiment, randomised block design with two replication at each open condition. The plot size was $5 \mathrm{~m}$ x $0.8 \mathrm{~m}$ and plants were raised at a spacing of $30 \times 10$ $\mathrm{cm}^{2}$. Standard cultural and plant protection practices were followed to raise good crop KAU (2011).

The crop was harvested when the 90 per cent of the pods in the plants were dried. All the observations were recorded after harvest except days Phenotypic, genotypic and environmental coefficients of variation were estimated by following the formula as suggested by Burton and De vane (1953).

Phenotypic coefficient of variation $(\mathrm{PCV})=$ $(\sigma p /$ Mean $) * 100$

Genotypic coefficient of variation $(\mathrm{GCV})=$ $(\sigma g /$ Mean $) * 100$

Environmental coefficient of variation (ECV) $=(\sigma \mathrm{e} / \text { Mean })^{*} 100$

Were $\sigma p, \sigma g$ and $\sigma e$ are phenotypic, genotypic and environmental standard deviations, respectively. According to Sivasubramanian and Madhavamenon (1973), PCV and GCV are classified as low if less than 10 per cent, moderate if is between 10 and 20 per cent, and high if is more than 20 per cent.to flowering.

\section{Stability analysis}

\section{Eberhart and Russel model}

Eberhart and Russell (1966) method was followed to estimate the three parameters of stability namely mean, regression coefficient (bi) and mean squared deviation $\left(\mathrm{s}^{2} \mathrm{di}\right)$ for each genotype.

The linear model proposed by Eberhart and Russell (1966) was

$Y i j=\mu i+b i l j+\sigma i j$

Where:

Yij $=$ Mean performance of $i^{\text {th }}$ genotype in $j^{\text {th }}$ environment

$\mu \mathrm{i}=$ Average performance of $\mathrm{j}^{\text {th }}$ genotype over all environments

bi $=$ Regression coefficient that measures the response of the $\mathrm{i}^{\text {th }}$ genotype to varying environments

$\sigma \mathrm{ij}=$ Deviation from regression of the $\mathrm{i}^{\text {th }}$ genotype at $\mathrm{j}^{\text {th }}$ environment.

$\mathrm{Lj}=$ Environmental index as the deviation of the mean of all genotypes in $\mathrm{j}^{\text {th }}$ environment from grand mean.

\section{Computation of regression coefficient}

The regression coefficient is one which is the regression of the performance of each genotype under different environments on the environmental means of over all the genotypes. This was estimated as follows.

$\mathrm{bi}=\varepsilon \mathrm{ijYijIj} / \varepsilon \mathrm{j} \mathrm{Ij}{ }^{2}$

Where, 
$\varepsilon \quad$ ijYijIj $=$ The sum of products of environmental index ( $\mathrm{Ij}$ ) with corresponding mean of that genotype at each environment (yij)

$\varepsilon j \mathrm{Ij}^{2}=$ the sum of the squares of the environmental index (Ij)

(a) For each value of regression coefficient $\mathrm{Ij}^{2}$ is common and equal to

$\varepsilon \mathrm{j} \mathrm{ij}^{2}=\mathrm{I}_{1}{ }^{2}+. .+\mathrm{Ii}^{2}+. . \mathrm{I}_{54}{ }^{2}$

(b) on the other hand $\varepsilon$ ijYijIj for each genotype is the sum of products of environmental index (Ij) with the corresponding mean $(x)$ of the genotype in each environment.

These values may be obtained in the following manner

$[\mathrm{X}] \mathrm{x}[\mathrm{Ij}]=[\varepsilon \mathrm{j} \mathrm{Yij} \mathrm{Ij}]=[\mathrm{S}]$

Where,

$[X]=$ matrix of means

$[\mathrm{Ij}]=$ Vector for environmental index and

$[\mathrm{S}]=$ Vector for sum of products $(\mathrm{Ie})$ \& $\mathrm{ij} Y \mathrm{ij} \mathrm{Ij}$

(c) Then bi values for each genotype was calculated by dividing $\varepsilon$ ijYijlj for each genotype by $\varepsilon \mathrm{j} l \mathrm{j}^{2}$

Where,

$\mathrm{Ij}=$ environmental index of $\mathrm{jth}$ environment which can be calculated as fallows.

\section{Computation of environmental index (Ij)}

$\mathrm{Ij}=\varepsilon \mathrm{i} Y \mathrm{ij} / \mathrm{g}-\varepsilon \mathrm{i} \varepsilon \mathrm{j} \mathrm{Yij} / \mathrm{ge}$ with $\varepsilon \mathrm{j} \mathrm{Ij}=0$

$=$ Total of all the genotypes at jth location Number of genotypes

$=$ Grand Total $/$ Total number of observations
Computation of mean square devitation $\left(\mathrm{S}^{2} \mathrm{di}\right)$ from linear regression $=S^{2} \mathrm{di}=(\varepsilon \mathrm{j}$ Sij $2 / \mathrm{e}-2$ $\left.-\mathrm{S} \mathrm{e}^{2} / \mathrm{r}\right)$

Where,

$\varepsilon j \mathrm{Sij}^{2}=\left[\varepsilon \mathrm{j} \mathrm{Y} \mathrm{Y}^{2} \mathrm{ij}-\mathrm{Yi}^{2} / \mathrm{g}\right]-(\varepsilon \mathrm{j} \mathrm{YijIj})^{2} / \varepsilon \mathrm{j} \mathrm{Ij}{ }^{2}$

Where,

$\varepsilon \mathrm{j} \mathrm{S}^{2} \mathrm{ij}=$ variance due to deviation from the regression for a genotype.

ci $\mathrm{Yij}^{2}-\mathrm{Yi}^{2} / \mathrm{g}=$ variance due to dependent variable

$(\varepsilon j Y i j I j)^{2} / \varepsilon j \mathrm{Ij}^{2}=[\varepsilon \mathrm{j}$ YijIj $)(\varepsilon \mathrm{j}$ YijIj $) / \varepsilon j \mathrm{Ij}^{2}$ $=$ bi $\varepsilon \mathrm{j} Y \mathrm{Yj} I j]$

From $\varepsilon$ j $\mathrm{S}^{2} \mathrm{ij}$ values the stability parameter $S^{2}$ di for each genotype is computed as fallows

$S^{2} \mathrm{di}=[\varepsilon \mathrm{j} \mathrm{Sij} /(\mathrm{e}-2)]-\mathrm{S}^{2} / \mathrm{r}$

Mean square Deviation from regression Deviation $=$

Degrees of freedom for each environment $=$ Pooled error $/$ Number of replications

$S^{2}=$ Estimate of pooled error

$r=$ Number of replications

$\mathrm{e}=$ Number of environments

$\mathrm{g}=$ Number of genotypes

\section{Results and Discussion}

Analysis of variance pooled over open condition (Table 1). There was significant deviation between environments for all the characters except test weight. Genotype and genotype $\mathrm{x}$ environment interaction was significant for all the traits tested. As the $G \times$ $E$ interaction was significant further statistical analysis was attempted by partitioning genotype $\mathrm{x}$ environment mean squares into 
components namely variance due to genotype $\mathrm{x}$ environment (linear) and pooled deviation (non-linear).

The analysis of variance for stability is presented in table 2. Environment (linear) was significant in all traits except plant height and test weight. $\mathrm{G} \times \mathrm{E}$ interaction linear was significant for number of branches, number of pods and yield per plant. Senthilkumar and Chinna (2012) also had the same opinion on these traits.

According to Eberhart and Russell (1966) an ideally adopted genotype could be the one having higher mean value, regression coefficient, bi $=1$ near unity with least deviation from regression $\mathrm{s}^{2} \mathrm{di}=0$.

Stability parameters of black gram genotypes pooled over open conditions. (Tables 3a and 3b)

\section{Days to flowering}

Days to flowering did not show any variation between the dates of planting under open condition indicating that the character is highly stable. However, studies by Senthilkumar and Chinna, (2012); Sowmini and Jayamani, (2013) and Singh et al., (2013), reported significant variations between days to flowering in blackgram genotypes. 2. Plant height even though the mean values ranged between $36.65 \mathrm{~cm}$ of $\mathrm{T} 12$ and $46.27 \mathrm{~cm}$ of T7, only T8 had significant bi value. However, significant $S^{2}$ di values was showed by many genotypes and T5, T7, T9, T13 and T14 were stable. As the height of the plant has effect on canopy coverage and hence tolerance to weed infestation, genotypes having tall plant stature is a desirable trait. 3 . Number of branches per plant, none of the genotypes had significant bi value. However, five genotypes had significant $S^{2}$ di values and hence, nine genotypes were stable for branches per plant. Senthilkumar and Chinna (2012), observed highly significant differences for number of branches per plant for thirty five blackgram genotypes over three diverse environments.

4. Number of pod bearing branches per plant, significant bi value was showed by $\mathrm{T} 8$ and significant $S^{2}$ di value was showed by T7. All other genotypes were showing stability for number of pod bearing branches per plant. Among these stable genotypes having high number of pod bearing branches per plant can be considered as superior. Rasul et al., (2012), suggested that branching is basically a genetic factor but environmental conditions may also influence the number of pod bearing branches per plant and play an important role in enhancing seed yield.

\section{Number of pods per plant}

For the character, number of pods per plant significant bi value was showed by T1, T9 and T14. While, significant $S^{2}$ di values were showed by T12. The genotypes T5, T7 and T8 with non-significant bi and $S^{2}$ di value and pods more than 40 per plant can be considered as superior. 6. Length of pod did not shown any variation between the three dates of sowing under open condition. However, studies in greengram by Nath and Dasgupta (2013) reported highly significant differences between genotypes and environment for length of pod.

7. Number of seeds per pod did not show any variation between the dates of planting under open condition indicating that the character is highly stable. Senthilkumar and Chinna (2012), reported three stable genotypes for the character number of seeds per pod. Nath and Dasgupta (2013), based on their studies in green gram identified seven genotypes exhibiting average stability for seeds per pod having bi value close to one. 8. For test 
weight, significant bi values were showed by $\mathrm{T} 1$ and T6 while significant $\mathrm{S}^{2}$ di was showed by T5, T8 and T12. Among the stable genotypes, T9 can be identified as having high mean value with more than $4.5 \mathrm{~g}$.

Table.1 Pooled ANOVA over three open conditions

\begin{tabular}{lcccccccc}
\hline $\begin{array}{l}\text { Source of } \\
\text { variation }\end{array}$ & df & $\begin{array}{c}\text { Plant } \\
\text { height } \\
\text { (cm) }\end{array}$ & $\begin{array}{c}\text { Number } \\
\text { of } \\
\text { branches } \\
\text { per plant }\end{array}$ & $\begin{array}{l}\text { Number } \\
\text { of pod } \\
\text { bearing } \\
\text { branches } \\
\text { per plant }\end{array}$ & $\begin{array}{c}\text { Number } \\
\text { of pods } \\
\text { per }\end{array}$ & $\begin{array}{c}\text { Test } \\
\text { weight } \\
(\mathbf{g})\end{array}$ & $\begin{array}{c}\text { Protein } \\
\text { content } \\
(\%)\end{array}$ & $\begin{array}{c}\text { Yield } \\
\text { per } \\
\text { plant } \\
(\mathbf{g})\end{array}$ \\
\hline Total & 41 & 27.89 & 3.55 & 4.09 & 124.68 & 0.13 & 3.27 & 6.84 \\
$\begin{array}{l}\text { Environments } \\
\text { (E) }\end{array}$ & 2 & $47.51^{*}$ & $64.92^{*}$ & $67.47^{*}$ & $\begin{array}{c}2069.08 \\
*\end{array}$ & 0.04 & $30.01^{*}$ & $44.58^{*}$ \\
Genotypes (G) & 13 & $26.29 *$ & $0.24^{*}$ & $0.54^{*}$ & $22.21^{*}$ & $0.21^{*}$ & $1.68^{*}$ & $7.78^{*}$ \\
G x E & 26 & $27.18^{*}$ & $0.48^{*}$ & $0.86^{*}$ & $26.34^{*}$ & $0.10^{*}$ & $2.01^{*}$ & $3.47^{*}$ \\
Pooled error & & 4.20 & 6.68 & 0.37 & 8.89 & 4.22 & 2.25 & 0.31 \\
\hline *Significance at $0.05 \%$ probability level & & & & & &
\end{tabular}

Table.2 Analysis of variance for stability for different traits under open condition

\begin{tabular}{|c|c|c|c|c|c|c|c|c|}
\hline $\begin{array}{l}\text { Source of } \\
\text { variation }\end{array}$ & df & $\begin{array}{l}\text { Plant } \\
\text { height } \\
\text { (cm) }\end{array}$ & $\begin{array}{c}\begin{array}{c}\text { Number } \\
\text { of } \\
\text { branches }\end{array} \\
\text { per plant }\end{array}$ & $\begin{array}{c}\begin{array}{c}\text { Number } \\
\text { of pod } \\
\text { bearing } \\
\text { branches } \\
\text { per plant }\end{array} \\
\end{array}$ & $\begin{array}{c}\text { Number } \\
\text { of pods } \\
\text { per } \\
\text { plant }\end{array}$ & $\begin{array}{c}\text { Test } \\
\text { weight } \\
\text { (g) }\end{array}$ & $\begin{array}{c}\text { Protein } \\
\text { content } \\
(\%)\end{array}$ & $\begin{array}{c}\text { Yield } \\
\text { per } \\
\text { plant } \\
\text { (g) }\end{array}$ \\
\hline Total & 41 & 27.89 & 3.55 & 4.00 & 124.68 & 0.13 & 3.27 & 6.84 \\
\hline Genotype(G) & 13 & 26.29 & 0.24 & 0.54 & 22.21 & $0.21^{*}$ & 60.02 & 7.78 \\
\hline $\begin{array}{l}\text { Environment } \\
\text {-linear (E) }\end{array}$ & 1 & 95.02 & $129.84 *$ & $134.94 *$ & $4138.15^{*}$ & 0.08 & $1.54^{*}$ & $89.17 *$ \\
\hline G x E linear & 13 & 21.47 & $0.71^{*}$ & 1.15 & $38.23 *$ & 0.13 & 1.54 & $1.06^{*}$ \\
\hline $\begin{array}{l}\text { Pooled } \\
\text { deviation-- } \\
\text { linear }\end{array}$ & 14 & 30.54 & 0.23 & 0.53 & 13.43 & 0.07 & 2.29 & 5.46 \\
\hline Pooled error & 42 & 4.20 & 0.06 & 0.37 & 8.89 & 0.04 & 0.02 & 031 \\
\hline $\begin{array}{l}\text { Nonlinear : } \\
\text { linear }\end{array}$ & & $1.42: 1$ & $0.74: 1$ & $0.46: 1$ & 035:1 & $0.53: 1$ & $1.48: 1$ & $5.15: 1$ \\
\hline
\end{tabular}

*Significance at $0.5 \%$ probability level 
Table.3a Estimates of stability pooled over open condition (Eberhart and Russell model)

\begin{tabular}{|c|c|c|c|c|c|c|c|c|c|c|c|c|}
\hline \multirow[t]{2}{*}{ Genotypes } & \multicolumn{3}{|c|}{ Plant height (cm) } & \multicolumn{3}{|c|}{$\begin{array}{c}\text { Number of branches per } \\
\text { plant }\end{array}$} & \multicolumn{3}{|c|}{$\begin{array}{c}\text { Number of pod bearing } \\
\text { branches per plant }\end{array}$} & \multicolumn{3}{|c|}{ Number of pods per plant } \\
\hline & Mean & bi & $\mathbf{S}^{2} \mathrm{di}$ & Mean & $\mathbf{B i}$ & $\mathbf{S}^{2} \mathrm{di}$ & Mean & bi & $\mathbf{S}^{2} \mathrm{di}$ & Mean & bi & $S^{2} \mathrm{di}$ \\
\hline $\mathbf{T 1}$ & 40.78 & 1.84 & $73.38^{*}$ & 5.05 & 0.88 & 0.01 & 4.55 & 0.73 & -0.14 & 35.20 & $0.93 *$ & -8.89 \\
\hline $\mathbf{T} 2$ & 39.90 & 1.65 & $26.30^{*}$ & 5.21 & 0.76 & $0.31 *$ & 4.63 & 0.78 & -0.16 & 37.83 & 1.23 & 0.98 \\
\hline T3 & 44.58 & 1.55 & $15.20^{*}$ & 5.26 & 0.65 & $0.29 *$ & 4.90 & 0.76 & 0.36 & 39.55 & 0.49 & -3.67 \\
\hline T4 & 42.33 & 3.02 & $88.93 *$ & 5.58 & 1.07 & 0.12 & 5.05 & 1.02 & -0.37 & 36.31 & 1.32 & 2.06 \\
\hline T5 & 44.29 & 2.88 & 0.81 & 5.23 & 0.64 & 0.03 & 4.71 & 0.63 & 0.13 & 40.68 & 1.21 & 7.59 \\
\hline T6 & 45.77 & 3.74 & $11.14^{*}$ & 5.58 & 0.97 & 0.03 & 5.11 & 0.85 & -0.17 & 39.95 & 0.91 & -6.52 \\
\hline T7 & 46.27 & -1.19 & 1.48 & 5.28 & 1.22 & $0.73 *$ & 6.03 & 1.93 & $3.01 *$ & 41.93 & 1.09 & 1.74 \\
\hline T8 & 44.65 & $-1.50^{*}$ & -4.17 & 5.33 & 0.92 & -0.06 & 5.05 & $0.87 *$ & -0.37 & 42.60 & 1.09 & -7.45 \\
\hline T9 & 40.26 & -1.60 & 3.66 & 5.23 & 1.00 & 0.02 & 4.76 & 0.90 & 0.30 & 39.65 & $1.48 *$ & -7.41 \\
\hline T10 & 42.50 & 0.59 & $3.23 *$ & 5.75 & 0.94 & $0.43 *$ & 5.55 & 0.95 & 0.12 & 37.70 & 1.58 & 11.52 \\
\hline T11 & 45.35 & 2.63 & $0.23 *$ & 4.91 & 0.85 & 0.08 & 4.56 & 0.90 & -0.35 & 34.35 & 0.86 & 8.42 \\
\hline T12 & 36.65 & 0.23 & $150.34 *$ & 5.96 & 1.72 & $0.39 *$ & 5.55 & 1.52 & 0.02 & 36.28 & 0.55 & $53.37 *$ \\
\hline T13 & 41.67 & 0.91 & -2.62 & 5.55 & 1.04 & -0.04 & 5.08 & 0.92 & -0.21 & 36.85 & 0.44 & 20.24 \\
\hline T14 & 37.76 & -0.77 & 1.71 & 5.65 & 1.27 & -0.08 & 5.10 & 1.17 & 0.04 & 34.10 & $0.73 *$ & -8.53 \\
\hline
\end{tabular}

* Significant at $0.05 \%$

Table.3b Estimates of stability for pooled over open condition (Eberhart and Russell model)

\begin{tabular}{|c|c|c|c|c|c|c|c|c|c|}
\hline \multirow[t]{2}{*}{ Genotypes } & \multicolumn{3}{|c|}{ Test weight (g) } & \multicolumn{3}{|c|}{ Yield per plant (g) } & \multicolumn{3}{|c|}{ Protein content $(\%)$} \\
\hline & Mean & bi & $S^{2}$ di & Mean & bi & $S^{2}$ di & Mean & bi & $S^{2}$ di \\
\hline T1 & 3.94 & $7.23 *$ & 0.05 & 12.99 & 1.08 & $2.37 *$ & 19.73 & 0.77 & $0.81^{*}$ \\
\hline $\mathbf{T 2}$ & 4.31 & 0.47 & -0.04 & 14.23 & 1.35 & $1.90^{*}$ & 19.98 & 0.55 & $2.64 *$ \\
\hline T3 & 4.39 & -2.72 & -0.02 & 15.46 & 0.96 & $17.10^{*}$ & 21.15 & 1.56 & $0.45^{*}$ \\
\hline T4 & 4.43 & -1.36 & 0.05 & 14.17 & 0.76 & $3.30 *$ & 20.48 & 0.85 & $0.20 *$ \\
\hline T5 & 4.59 & 2.18 & -0.05 & 14.95 & 0.89 & -0.14 & 21.19 & 1.17 & $0.34 *$ \\
\hline T6 & 4.77 & $-9.29 *$ & 0.05 & 17.30 & 1.67 & $8.77 *$ & 20.40 & 1.99 & $0.22 *$ \\
\hline T7 & 4.37 & -3.48 & $0.44 *$ & 15.02 & $1.58 *$ & -0.30 & 20.39 & 1.64 & $4.85^{*}$ \\
\hline T8 & 4.01 & 7.08 & $0.17 *$ & 16.13 & 1.35 & $13.79 *$ & 21.54 & 1.74 & $6.13 *$ \\
\hline T9 & 4.54 & -0.35 & 0.04 & 15.10 & 0.45 & 0.28 & 19.81 & 0.38 & $3.12 *$ \\
\hline T10 & 4.36 & -2.83 & 0.07 & 15.30 & 0.50 & $19.27 *$ & 20.30 & 1.17 & $0.23 *$ \\
\hline T11 & 4.17 & 1.60 & -0.02 & 12.36 & 1.21 & -0.17 & 20.33 & 1.15 & $6.63 *$ \\
\hline T12 & 3.92 & 3.14 & $0.27 *$ & 13.15 & 0.96 & 1.42 & 18.77 & -0.10 & $0.82 *$ \\
\hline T13 & 4.07 & 6.21 & -0.04 & 12.03 & 0.35 & $2.21^{*}$ & 19.52 & 0.42 & $1.04 *$ \\
\hline T14 & 3.95 & 6.11 & 0.01 & 11.96 & 0.82 & $2.37 *$ & 19.48 & 0.64 & $4.29 *$ \\
\hline
\end{tabular}

* Significant at $0.05 \%$ 
Table.4 Total scores and ranks of genotypes under open condition

\begin{tabular}{|c|c|c|c|c|c|c|c|c|c|c|c|c|}
\hline Genotypes & $\begin{array}{c}\text { Plant } \\
\text { height } \\
\text { (cm) }\end{array}$ & Stability & $\begin{array}{c}\begin{array}{c}\text { Number } \\
\text { of pods } \\
\text { per } \\
\text { plant }\end{array} \\
\end{array}$ & Stability & $\begin{array}{l}\text { Number } \\
\text { of seeds } \\
\text { per pod }\end{array}$ & Stability & $\begin{array}{c}\text { Test } \\
\text { weight } \\
\text { (g) }\end{array}$ & Stability & $\begin{array}{c}\text { Yield } \\
\text { per } \\
\text { plant } \\
\text { (g) }\end{array}$ & Stability & $\begin{array}{l}\text { Total } \\
\text { score }\end{array}$ & Rank \\
\hline T1 & 1 & 2 & 12 & 2 & 5 & 1 & 13 & 2 & 11 & 2 & 51 & 11 \\
\hline $\mathbf{T} 2$ & 2 & 2 & 7 & 1 & 10 & 1 & 8 & 1 & 8 & 2 & 42 & 9 \\
\hline T3 & 1 & 2 & 6 & 1 & 7 & 1 & 5 & 1 & 3 & 2 & 29 & 5 \\
\hline T4 & 1 & 2 & 10 & 1 & 4 & 1 & 4 & 1 & 9 & 2 & 35 & 7 \\
\hline T5 & 1 & 1 & 3 & 1 & 6 & 1 & 2 & 1 & 7 & 1 & 24 & 3 \\
\hline T6 & 1 & 2 & 4 & 1 & 2 & 1 & 1 & 2 & 1 & 2 & 17 & 1 \\
\hline T7 & 1 & 1 & 2 & 1 & 8 & 1 & 6 & 2 & 6 & 2 & 30 & 6 \\
\hline T8 & 1 & 2 & 1 & 1 & 5 & 1 & 11 & 2 & 2 & 2 & 28 & 4 \\
\hline T9 & 1 & 1 & 5 & 2 & 1 & 1 & 3 & 1 & 5 & 1 & 21 & 2 \\
\hline T10 & 1 & 2 & 8 & 1 & 13 & 1 & 7 & 1 & 4 & 2 & 40 & 8 \\
\hline T11 & 1 & 2 & 13 & 1 & 11 & 1 & 9 & 1 & 12 & 1 & 52 & 12 \\
\hline T12 & 2 & 2 & 11 & 2 & 12 & 1 & 14 & 2 & 10 & 1 & 57 & 13 \\
\hline T13 & 1 & 1 & 9 & 1 & 6 & 1 & 10 & 1 & 13 & 2 & 45 & 10 \\
\hline T14 & 2 & 1 & 14 & 2 & 9 & 1 & 12 & 1 & 14 & 2 & 58 & 14 \\
\hline
\end{tabular}




\section{Yield per plant}

Yield being the most important criteria for selection in any breeding programme identification of genotype with high mean value and non-significant bi and $S^{2}$ di value is essential. However, most of the genotypes were having significant bi and $\mathrm{S}^{2}$ di values indicating the effect of environment on the expression of the character. Most of the genotypes having high yield were not stable. Among the stable genotypes, the genotype, 5 and 9 had yield per plant of more than $14 \mathrm{~g}$. Shanthi et al., (2007), studied twenty blackgram genotypes for stability under three environments and identified four genotypes with high yield potential and stability over environments.

\section{Protein content}

In blackgram genotypes varied between 18.77 and 21.54 per cent. None of the genotypes had significant bi values. However, Chaudhary and Paroda (1980), advocated that linear regression could simply regarded as measure of response of a particular genotype, where the deviation from regression as a measure of stability. In the study all the genotypes were showing significant $\mathrm{S}^{2} \mathrm{di}$ indicating that the genotypes were not stable for protein content. Chaudhari et al., (2013), based on their study on 36 genotypes of cowpea under four seasons observed that magnitude of genotype $\mathrm{x}$ environment linear and pooled deviation from linearity was high for protein content.

The present study revealed that no genotype was stable for all the traits studied. Senthilkumar and Chinna (2012), also could not identify any single variety stable for all the traits. According to Eberhart and Russell model a good genotype is the one with high mean value and non-significant bi and $\mathrm{S}^{2} \mathrm{di}$ values.
Considering yield and major yield contributing traits the genotypes were ranked as suggested by Arunachalam and Bandyapadhyay (1984). For stable genotypes rank 1 was given and for unstable rank 2. For plant height, as the optimum height preferred was $40-50 \mathrm{~cm}$, genotypes falling in this category was given rank 1 and others rank 2 . The genotypes were raked from 1 to 14 for the major traits namely, number of pods per plant, number of seeds per pod, test weight and yield per plant. Based on the ranks scoring was done for the genotypes as given in table 4 . The genotype with lowest score was given rank one followed by other lower scores. The genotypes T6, was the best followed by $\mathrm{T} 9$ and $\mathrm{T} 5$ suitable for cultivation under open condition.

\section{References}

Arunachalam, V., and Bandyopadhyay, A. 1984. A method to make decisions jointly on a number of dependent characters. Indian J. Genet., 44 (3): 419-424.

Chaudhari, S. B., Naik, M. R., Patil. S. S., and Patel, J. D. 2013.Stability analysis in Cowpea [Vigna unguiculata (L) Walp.]. Trends in Biosci. 6 (4): 450-456.

Chaudhary, B. S., and Paroda, R. S. 1980.Phenotypic stability for protein content in relation to homogenous and hetrogenous population in wheat. Indian J. Genet. Plant Breed, 40 (1): 127$131 \mathrm{pp}$.

Eberhart, S.A., and Russell, W. A. 1966.Stability parameter for comparing varieties. Crop Sci. 6: 36-40.

KAU (Kerala Agricultural University) 2011.Package of Practices Recommendations: Crops (14 ${ }^{\text {th }}$ Ed.). Kerala Agricultural University, Thrissur, 360p.

Nath, D., and Dasgupta, T. 2013. Genotype x Environment Interaction and Stability 
Analysis in Mungbean. J. Of Agric. and Veterinary Sci. 5(1): 2319-2372.

Rasul, F., Cheema, M. A. Sattar, M., Saleem, F. and Wahid, M. A. 2012. Evaluating the performance of three mungbean varieties grown Under varying inter-row spacing. The J. Anim. Plant Sci., 22(4): 1030-1035.

Senthilkumar, N., and Chinna, S. K. 2012.Stability for seed yield in black gram (Vigna mungo L. Hepper). Intl J. Of Recent Sci. Res. Vol. (3) 336 339pp.

Shanthi, P., Jebaraj, S. and Murugan, E. 2007. Stability analysis in black gram (Vigna mungo (L.) Hepper). Legume Res.,
30(2): 154-156.

Singh, G., Kaur, H., Navneet, A., Hari, R., Gill, K. K. and Khanna, V. 2013.Symbiotic efficiency, thermal requirement and yield of blackgram (Vigna mungo L. Hepper) genotypes as influenced by sowing time. Indian $J$. Agric. Sci. 83 (9): 953-8.

Sowmini, K., and Jayamani, P. 2013. Genetic variability studies for yield and its component traits in RIL population of black gram (Vigna mungo (L.) Hepper). Electronic J. Plant Breed. Genet. 4(1): 1050-1055.

\section{How to cite this article:}

Gambhire, V.B., D.M. Raut, S.J. Dhakulkar and Jiji joseph. 2017. Genotype x Environment Analysis of Blackgram (Vignamungo L. Hepper) Cultures over Open Condition by Eberhart and Russell Model. Int.J.Curr.Microbiol.App.Sci. 6(9): 1955-1963.

doi: https://doi.org/10.20546/ijcmas.2017.609.239 